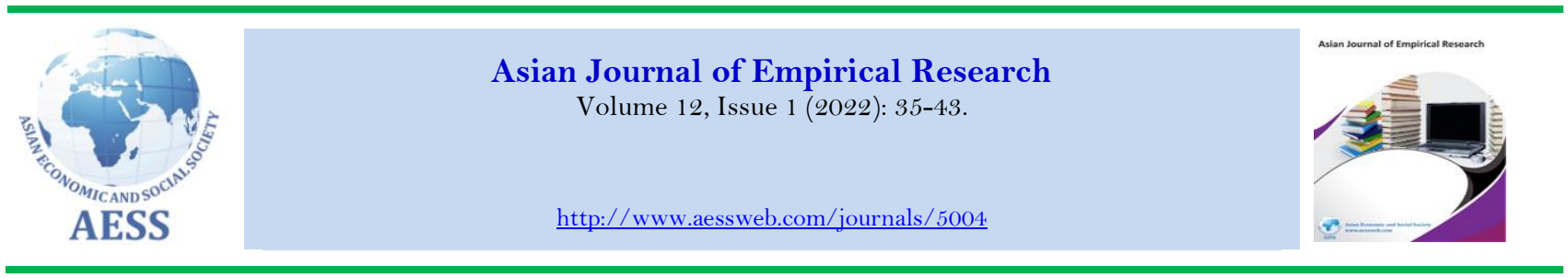

\title{
LINKING INDUSTRIALIZATION AND EDUCATION IN SUB-SAHARAN AFRICAN COUNTRIES
}

\author{
(iD) Moutie Giscard Valery ${ }^{\mathrm{a}}$ \\ (iD) Gladys Njang Che ${ }^{b}$ \\ iD Guivis Zeufack Nkemgha ${ }^{\text {" }}$
}

\author{
${ }^{a}$ University of Buea, Buea, Cameroon. \\ ${ }_{b .}^{b}$ University of Bamenda, Bamenda, Cameroon. \\ هnkemghazeufackguivis@yahoo.fr (Corresponding author)
}

\section{Keywords \\ Industrialization \\ Education \\ Income per capita}

Article History

Received: 22 December 2021

Revised: 26 January 2022

Accepted: 8 February 2022

Published: 16 February 2022

JEL Classification

$\mathrm{O} 25$; 2 1; $\mathrm{O} 55$.

\begin{abstract}
Several works have studied the consequences of industrialization on macroeconomic variables. However, the relationship between industrialization and education has not yet been studied, especially in sub-Saharan Africa (SSA). The objective of this study is to fill this limitation of the literature by analyzing the direct effect of industrialization on education in 23 SSA countries during the period 2000-2018. Moreover, we analyzed the indirect effect between the two variables through the transmission channels. To achieve our objective, we mobilized the Driscoll and Kraay methods and System GMM. The results reveal that there is a negative and significant relationship between industrialization and education. Moreover, urbanization and per capita income are transmission channels that contribute to mitigating this negative effect. Finally, our results show that the positive impact of the processing sector on education in SSA is conditioned by the achievement of a certain per capita income threshold and a certain urbanization threshold.
\end{abstract}

Contribution/Originality: This paper is the first macroeconomic study that assesses the effect of industrialization on education. It also highlights the indirect effect of industrialization on education through per capita income and urbanization. Finally, the net effect and the thresholds of the transmission channels through which industrialization positively impacts education was found.

DOI: $10.18488 / 5004 . v 12 \mathrm{i} 1.4423$

$\operatorname{ISSN}(\mathrm{P}):$ 2306-983X/ ISSN(E): 2224-4425

How to cite: Moutie Giscard Valery --- Gladys Njang Che --- Guivis Zeufack Nkemgha (2022) Linking Industrialization and Education in Sub-Saharan African Countries. Asian Journal of Empirical Research, 12(1), 35-43. $10.18488 / 5004 . v 12 \mathrm{i} 1.4423$

(C) 2022 Asian Economic and Social Society. All rights reserved.

\section{INTRODUCTION}

Considering the fact that education is not free, so it is not easy to get. If it is considered as an input to develop the human resources necessary for economic and social transformation, it can also be considered as a consumer good; because it offers utility (satisfaction) to the consumer. Moreover, the hypothesis according to which formal education is useful for improving the productive capacity of a population is that advocated by the theory of human capital.

At the end of the MDG journey, despite the many progress made, it was clear that the world still had many children out of school and of school age (about 57 million according to the UN (2015)). Aware of the failure to achieve this objective, the international community has integrated the objective of ensuring education for all and at all ages into the SDG agenda. According to human capital theorists (Becker, 1962; Lucas, 1990; Mincer, 1958), an educated population is a productive population. According to this theory, an important condition for promoting the development of a country is the improvement of the level of education of the population. It is for this reason that it is important to understand the explanatory factors of the level of education. The analysis of the specific case of SSA countries is justified by the fact that this region is the first in the world to record the highest rate of exclusion from education. With a $21 \%$ school exclusion rate, SSA has a higher rate than North Africa (11\%) (Institute of Statistics for UNESCO, 2019). 
Moreover, more than a fifth of children aged around 6 to 11 are out of school, followed by a third of children aged around 12 to 14 and almost $60 \%$ of young people aged around 15 at 17 are out of school (Institute of Statistics for UNESCO, 2019). Several explanations are at the origin of the high rate of exclusion in education in SSA, in particular unemployment, the low level of per capita income, the high level of child labor, social inequalities, the low level of investment in education, poor governance and socio-political instabilities.

However, many studies have shown that industrialization is a solution to economic development through poverty reduction (Cadot, De Melo, Plane, Wagner, \& Woldemichael, 2016) and the improvement of human capital (Federman \& Levine, 2005). The first studies on the relationship between industrialization and economic development date back to the 1950s. To this end, the work of Rodrik (2008); Rodrik (2009) cited by Goujon and Kafando (2011) showed that industrialization boosts economic growth. Recognizing this relationship, many developing countries, such as African countries, adopted in the 1960 s and 1970 s an import substitution model of locally producing the goods needed to meet domestic demand and protect local businesses from foreign competition.

According to the UNIDO (2002) and Hausmann, Pritchett, and Rodrik (2005) industrialization is seen as the catalyst for long-term economic growth. According to Cadot et al. (2016) industrialization is a factor in poverty reduction. It also contributes to improving the quality of human capitalfreeman (Federman \& Levine, 2005). Moreover, it contributes to the reinforcement of economic diversity and national investments (Duarte \& Restuccia, 2010). According to UNCTAD and UNIDO (2011), African countries are committed to a broader agenda that aims to diversify their economies, create more jobs, better withstand shocks and reduce poverty in recent years.

Recent initiatives on the continent in terms of industrial development have had varying levels of success depending on the experience. While some models seem to be more successful than others, few experiences can be directly replicated from one country to another. The potential of the African continent is well established: seven of the ten countries with the strongest economic growth in the world are in Africa (AfDB, 2017).

Industrialize Africa is one of the five accelerators of the African Development Bank, the other four being Light Up and Power Africa, Feed Africa, Integrate Africa and Improve People's Quality of Life. This is why the industrialization of Africa is at the heart of the "High 5s" of the African Development Bank. To industrialize Africa, the African Development Bank is committed to raising capital, reducing investment risks for the private sector and leveraging capital markets. These are all essential measures to implement the continent's industrial agenda and build a 21 st century Africa well equipped to take its place in global value chains (AfDB, 2017).

Several works on the theoretical level (Marx \& Engels, 1848; Smith, 1776) have demostrated that industrialization is a determinant of development. Implicitly, industrialization improves the well-being of a nation on several dimensions including education. Through the flexibility of the workforce, the increase in incomes that it stimulates, industrialization contributes to creating a growing level of education for all (Kerr, 1962). Therefore, the industrialization of a country or a region influences not only the social and cultural life with educational opportunities, housing and other infrastructures but it also influences the economic life of the populations through the increased income and job opportunities. In contrast, Adam Smith and Marx revealed the potential downsides of industrialization, including growing inequality, increased pollution, and weaker social cohesion. Indeed, some concerns relate to how industrialization can contribute to deschooling by attracting young people to work in factories or by increasing the need for young people to help at home.

The analysis of the effect of industrialization on education has already been an important concern of the literature. For example, the gradual introduction of large-scale steam-powered factories has been observed to promote the development of low-skilled jobs and the decline of semi-skilled jobs in Britain, eventually reducing the literacy rate and education in this country (De Pleijt \& Weisdorf, 2016). This consequence is particularly justified because steam engines favored children who performed secondary tasks to help older workers. These included the assembly of broken pieces of yarn on spinning mules in the textile sector (Nardinelli, 1980, 1990). Sanderson (1972) and Nicholas and Nicholas (1992) referred to this situation as the "deskilling hypothesis". Moreover, the same phenomenon has been observed at the level of secondary education in the USA (Goldin \& Katz, 1997). However, Tendler (2002) finds that there is heterogeneity within the manufacturing sector and that many jobs are not designed to be profitable for high school education. Even if it should be specified in the case of French or English industrialization that it was not easy to prove that industrialization was the cause of a drop in the literacy rate (Corbin, 1975; Schofield, 1973) because during the period of the rise of industrial activities (early 19th century), Laqueur (1974) declared that there was rather an increase in the said rate

It can be deduced from the above that the relationship between the processing sector and education is not conclusive. The work of Leblond (1970) demonstrated the presence of a low literacy rate in the industrial districts between 1831 and 1843 in northern France. The case of the USA has been studied, among others, by Goldin and Katz (1999). These authors observed that there was a negative association between industrialization and education. However other authors have instead found a positive relationship between the two variables. For the case of Indonesia, Federman and Levine (2005) demonstrated that the processing sector promotes education at all levels. Along the same lines, Sharma, Vashist, and Sharma (2008) found that industrialization has improved education as well as economic and social infrastructure. This was also the case in Mexico for primary education.

In summary, the empirical literature on the the link between the manufacturing sector and education, although scarce, remains ambiguous. Through increased public sector incomes, returns to skills and children's access to school, industrialization can increase education. At the same time, the expansion of manufacturing jobs can reduce education by increasing the opportunity costs of keeping children in school, reducing the return to skills (in case manufacturing jobs are very low-skilled) and by inducing migration and other social disruptions that can hinder school attendance. The lack of consensus on the relationship between the two variables is proof that other work can be carried out on this 
relationship in order to contribute more to the literature on this subject. It is in this context that our subject finds, among other things, its full justification.

Besides studying the relationship between industrialization and education, it is important to study the channels through which industrialization impacts education. To this end, the literature has enabled us to identify two potential transmission channels. These include urbanization and per capita income.

The work of Kerr (1962) argues that family income can improve as a result of industrialization if workers have the bargaining power to share in productivity gains. Since education is limited by money or represents a normal good, an improvement in parental income leads to an increase in the demand for education. Similarly, industrialization can also increase the supply side of education through increased government revenue. It can be concluded from the above that industrialization generates employment and increases the opportunity cost of pursuing education. Beyond the work of Kerr (1962); Le Brun, Helper, and Levine (2011) argue that industrialization contributes to increased urbanization and can benefit students by bringing them closer to schools and making them more accessible. Nor is it excluded that we are witnessing rapid demography due to urbanization, the construction of infrastructures of which thus leads to poor learning conditions.

The literature on the relationship between industrialization and education is not unanimous. Moreover, the case of sub-Saharan African countries has not yet attracted the attention of previous works. Yet, SSA represents the region where the rate of exclusion in education is the highest of all the regions of the world. The objective of this article is to compensate for this lack of literature by analyzing how industrialization impacts education in SSA countries. Indeed, the processing sector should increase not only family incomes but also those of the public sector. If public sector income stimulates the supply of education, family income should increase the demand for education. However, the particularity of SSA, which records a high rate of school exclusion in the world, gives us the opportunity to analyze whether industrialization contributes to the process of deschooling in this region. In addition, we will seek to further understand this relationship by highlighting the channels through which industrialization impacts education.

This paper has four sections. In addition to section one that includes the introduction, section two of this work is devoted to the methodological approach. As for section three, it highlights the results of the study and section four concludes.

\section{DATA AND METHODOLOGY}

\subsection{Data}

We use a panel of $23 \mathrm{SSA}$ countries with data from 2000 to 2018. The data for our variables are taken from the World Bank's indicator database. It is important to specify that the limitation of the study period and the number of countries is linked to the availability of data.

Table 1. Descriptive statistics.

\begin{tabular}{l|c|c|c|c|c|c}
\hline Variables & Obs. & Mean & Median & Std. Dev. & Min & Max \\
\hline Indust & 437 & 9.512 & 9.201 & 4.425 & 0.230 & 21.21 \\
\hline Agricult & 437 & 23.793 & 23.981 & 12.672 & 2.085 & 58.651 \\
\hline Pop & 437 & 2.741 & 2.766 & 0.641 & 0.239 & 4.627 \\
\hline Water & 437 & 55.018 & 54.312 & 13.845 & 19.897 & 92.279 \\
\hline Sanitation & 437 & 25.714 & 22.691 & 14.269 & 4.328 & 74.821 \\
\hline Goveff & 437 & -0.845 & -0.833 & 0.456 & -1.744 & 0.693 \\
\hline Polist & 437 & -0.797 & -0.666 & 0.783 & -2.664 & 0.661 \\
\hline Urban & 437 & 15.688 & 12.812 & 10.842 & 4.273 & 64.201 \\
\hline GDPC & 437 & 1153.371 & 659.526 & 1411.072 & 149.361 & 8080.862 \\
\hline Education1 & 437 & 96.144 & 99.349 & 22.821 & 32.351 & 149.303 \\
\hline Education2 & 437 & 36.053 & 33.841 & 18.285 & 6.192 & 109.442 \\
\hline Education3 & 437 & 5.936 & 4.644 & 4.527 & 0.345 & 20.484 \\
\hline
\end{tabular}

The dependent variable in this paper is education. This variable is increasingly used in the literature by the three levels of the schooling rate (Federman \& Levine, 2005; Goldin \& Katz, 1999; Le Brun et al., 2011). As for the main explanatory variable (industrialization), it is captured by the added value of the manufacturing sector. In addition, several authors have already used this measure in their work (Njangang \& Nounamo, 2020; Nkoa, 2016). In addition to this variable, other control variables were used as explanatory factors for education (access to sanitation, access to water, agriculture and population growth rate). The sources of the different variables, their definitions as well as the list of individuals in our panel are contained in Tables A 1 and A2 in the appendix.

The descriptive statistics and the result of the cross-sectional dependence test of Pesaran (2004) are recorded respectively in Table 1 and Table 2 . Table 2 shows that all the variables admit a transverse dependence with regard to their probability which is zero. The paragraph below provides a brief description of the expected signs.

Referring to the work of Goldin and Katz (1999) they found an inverse relationship between the manufacturing sector and education, while the work of Federman and Levine (2005) rather revealed a positive association between the two variables. Regarding access to sanitation and access to water, they all impact education (Santiago, Resende, \& Dinar, 2016). As for demography, Bilsborrow (1978) found that it had no effect on education. Finally, the work of Engler and Kretzer (2014) has proven that agriculture has a positive effect on education. 
Table 2. Pesaran cross-dependency test (Pesaran, 2004).

\begin{tabular}{l|c|c|c|c}
\hline Variables & CD-Test & P-Value & Corr. & Abs. (corr.) \\
\hline Education1 & 22.141 & 0.000 & 0.319 & 0.609 \\
\hline Education2 & 52.328 & 0.000 & 0.755 & 0.909 \\
\hline Education3 & 51.080 & 0.000 & 0.737 & 0.797 \\
\hline Totalrent & 14.396 & 0.000 & 0.208 & 0.414 \\
\hline Indust & 8.491 & 0.000 & 0.122 & 0.423 \\
\hline Agricult & 5.083 & 0.000 & 0.073 & 0.381 \\
\hline Pop & 4.157 & 0.000 & 0.060 & 0.532 \\
\hline Water & 28.492 & 0.000 & 0.411 & 0.959 \\
\hline Sanitation & 20.738 & 0.000 & 0.299 & 0.971 \\
\hline
\end{tabular}

\subsection{Methodology}

From the recent literature on education (Santiago et al., 2016) we have formulated the following econometric model in order to achieve our objective:

$$
\text { Education }_{i t}=\beta_{0}+\beta_{1} \text { Education }_{i t-1}+\beta_{2} \text { Indust }_{i t}+\beta_{3} X_{i t}+\mu_{i}+v_{t}+\varepsilon_{i t}
$$

${\text { Where } \text { Indust }_{i t} \text { and Education }}_{i t}$ represent respectively industrialization and education for country $i$ in the period $t, X_{i t}$ is a vector which includes all control variables, $\mu_{i}$ is an unobserved country-specific effect, $v_{t}$ is the time specific effect and $\varepsilon_{i t}$ is the error term.

When all the variables of an econometric model admit a cross-sectional dependence, the use of the technique of Driscoll and Kraay is required. This technique allows us to make estimates from fixed effects and pooled Ordinary Least Squares. For a static panel, the use of this method provides the standard deviations of coefficients which are robust. Our approach is to use OLS as a basic estimation technique. Given the fact that it does not capture fixed effects, we will use fixed effects in the following. Then, our econometric model being dynamic and not static, the use of the previous method is likely to provide biased results because of the lagged dependent variable present in the model as an independent variable $\left(\right.$ Education $\left._{i t-1}\right)$. And according to the work of Nickell (1981) this lagged variable is correlated with the error term and thus generates the endogenity problem. To take into account the dynamic nature of our panel, the problem of endogeneity or reverse causality, we used a method with instrumental variables: the system Generalized Method of Moments (GMM). This method was proposed by Arellano and Bond (1991); Arellano and Bover (1995) and Blundell and Bond (1998).

\section{RESULTS}

The tables below provide the results from the different estimates. Table 3 records the results obtained by the OLS and fixed effects methods. With regard to Table 4, it presents the results obtained by the GMM method. Finally, Table 5 reproduces the results presented in Table 4 by introducing potential transmission channels.

\subsection{Baseline Results}

Table 3 reveals through the use of the grouped OLS method that there is an inverse relationship between education and industrialization. Consequently, an increase in the added value of the manufacturing sector by $1 \%$ leads to a drop in the schooling rate by $0.25 \% ; 0.32 \%$ and $0.08 \%$ respectively for the three levels of education. This result is compatible with that of the fixed effects method, the results of which are recorded in the same table.

Table 3. Industrialisation and education (baseline results).

\begin{tabular}{|c|c|c|c|c|c|c|}
\hline \multicolumn{7}{|c|}{ Driscoll and Kraay } \\
\hline \multirow[t]{2}{*}{ Variables } & \multicolumn{3}{|c|}{ Fixed effects } & \multicolumn{3}{|c|}{ Pooled OLS } \\
\hline & Education 1 & Education2 & Educations & Education 1 & Education2 & Education3 \\
\hline Indust & $\begin{array}{c}-0.5158^{*} \\
(0.09)\end{array}$ & $\begin{array}{c}-0.4243^{*} * * \\
(0.00)\end{array}$ & $\begin{array}{c}-0.0580^{* * *} \\
(0.01)\end{array}$ & $\begin{array}{c}-0.2561 * * \\
(0.02)\end{array}$ & $\begin{array}{c}-0.3268^{* * *} \\
(0.01)\end{array}$ & $\begin{array}{c}-0.0826^{*} * \\
(0.03)\end{array}$ \\
\hline Agricul & $\begin{array}{c}-0.3097 \\
(0.1)\end{array}$ & $\begin{array}{c}-0.1190 \\
(0.1)\end{array}$ & $\begin{array}{c}-0.0582 \\
(0.1)\end{array}$ & $\begin{array}{c}-0.4305^{* * *} * \\
(0.00)\end{array}$ & $\begin{array}{c}-0.0945^{* * *} * \\
(0.00)\end{array}$ & $\begin{array}{c}-0.0241 \\
(0.1)\end{array}$ \\
\hline Pop & $\begin{array}{c}-4.9971^{*} \\
(0.07)\end{array}$ & $\begin{array}{c}1.4510^{*} \\
(0.06)\end{array}$ & $\begin{array}{c}0.6607^{* * * *} \\
(0.00)\end{array}$ & $\begin{array}{c}-5.1005^{* * * *} \\
(0.00)\end{array}$ & $\begin{array}{c}-5.3027^{* * * *} \\
(0.00)\end{array}$ & $\begin{array}{c}-0.3861 \\
(0.5)\end{array}$ \\
\hline Water & $\begin{array}{c}-0.1554 \\
(0.4)\end{array}$ & $\begin{array}{c}1.0026^{* * * *} \\
(0.00)\end{array}$ & $\begin{array}{c}0.0807 * * * \\
(0.00)\end{array}$ & $\begin{array}{c}-0.2020^{*} \\
(0.07)\end{array}$ & $\begin{array}{l}0.4074^{* * * *} \\
(0.00)\end{array}$ & $\begin{array}{l}0.0739 * * * \\
(0.00)\end{array}$ \\
\hline Sanitation & $\begin{array}{c}1.6317^{* * * *} \\
(0.00)\end{array}$ & $\begin{array}{l}0.1341^{* *} * \\
(0.04)\end{array}$ & $\begin{array}{c}0.2487^{* * * *} \\
(0.00)\end{array}$ & $\begin{array}{c}0.0007 \\
(0.9)\end{array}$ & $\begin{array}{c}0.4595^{* * * *} \\
(0.00)\end{array}$ & $\begin{array}{c}0.1416^{* * * *} \\
(0.00)\end{array}$ \\
\hline Cons & $\begin{array}{c}88.7055^{* * * * *} \\
(0.00)\end{array}$ & $\begin{array}{c}-19.664^{* * * *} \\
(0.00)\end{array}$ & $\begin{array}{c}-4.7779^{* * * *} \\
(0.00)\end{array}$ & $\begin{array}{c}133.8988^{* * * *} * \\
(0.00)\end{array}$ & $\begin{array}{c}21.7121^{* * * * *} \\
(0.00)\end{array}$ & $\begin{array}{c}0.6430 \\
(0.8)\end{array}$ \\
\hline $\mathrm{R}^{2}$ & 0.242 & 0.4513 & 0.355 & 0.058 & 0.572 & 0.455 \\
\hline Prob.(F-stat) & 0.000 & 0.000 & 0.000 & 0.000 & 0.000 & 0.000 \\
\hline Nb. Obs. & 437 & 437 & 437 & 437 & 437 & 437 \\
\hline
\end{tabular}

probabilities. 
Previous methods established an inverse relationship between industrialization process and education. However, the possibility of reverse causation, endogeneity, or unobserved heterogeneity can bias the results and call our results into question. To deal with these potential problems, we estimate Equation 1 using system GMMs. The results of this estimate are contained in Table 4.

\subsection{System GMM Regression}

The analysis of the effect of the manufacturing sector on education through the GMM method gives results which are recorded in Table 4. Like the previous methods, the GMM method finds that industrialization constitutes an obstacle to education. Therefore, an increase in industrialization of $1 \%$ leads to a drop in the enrollment rate of $0.11 \%$; $0.06 \%$ and $0.03 \%$ respectively for the three levels of education. This situation can be explained by the fact that the processing sector attracts young people to the factory and, according to Le Brun et al. (2011) it is difficult to combine school and work in the manufacturing sector. According to the World Bank (2016) the SSA region alone concentrates $41 \%$ of the monetary poverty rate in the world and the slightest job opportunity is seized by young people in order to improve their living conditions and that of their family. Obtaining these jobs immediately increases the opportunity cost of education. This result is consistent with the work of De Pleijt (2018) who demonstrated that the demand for education and literacy declined in England following industrialization. Thus, the deskilling hypothesis of Nicholas and Nicholas (1992) is confirmed for SSA countries.

To test the robustness of our results, we regress Equation 1 using the GMM method with more control variables. The results of this estimation are reported in columns 4-6 of Table 4. Government effectiveness and political stability are the additional control variables we use for sensitivity purposes. In summary, the results obtained in columns 4-6 of Table 4 are robust with regard to the significance of their coefficient.

Table 4. The reponse of education to industrialiazation through the GMM regression.

\begin{tabular}{|c|c|c|c|c|c|c|}
\hline \multirow[t]{2}{*}{ Variables } & 1 & 2 & 3 & 4 & 5 & 6 \\
\hline & Education 1 & Educatione & Education3 & Education 1 & Education2 & Education3 \\
\hline Indust & $\begin{array}{c}-0.1110^{* *} \\
(0.03)\end{array}$ & $\begin{array}{c}-0.0681^{*} \\
(0.05)\end{array}$ & $\begin{array}{c}-0.0306^{* * *} \\
(0.00)\end{array}$ & $\begin{array}{c}-0.1137^{*} * * \\
(0.00)\end{array}$ & $\begin{array}{c}-0.1427 * * * \\
(0.00)\end{array}$ & $\begin{array}{c}-0.0649^{* *} \\
(0.01)\end{array}$ \\
\hline Agricul & $\begin{array}{c}-0.8026^{* * * *} \\
(0.00)\end{array}$ & $\begin{array}{c}-0.0245^{* *} \\
(0.01)\end{array}$ & $\begin{array}{c}-0.0076^{* * *} * \\
(0.00)\end{array}$ & $\begin{array}{c}-0.0827 * * * \\
(0.00)\end{array}$ & $\begin{array}{c}-0.0733^{* * *} \\
(0.00)\end{array}$ & $\begin{array}{c}-0.0079^{* *} \\
(0.01)\end{array}$ \\
\hline Pop & $\begin{array}{c}-1.8209^{* * *} * \\
(0.00)\end{array}$ & $\begin{array}{c}-0.6290^{*} \\
(0.06)\end{array}$ & $\begin{array}{c}-0.4239^{* * *} * \\
(0.00)\end{array}$ & $\begin{array}{c}-1.5649^{* * * *} \\
(0.00)\end{array}$ & $\begin{array}{c}-0.7295^{* *} \\
(0.02)\end{array}$ & $\begin{array}{c}-0.3705^{* * *} \\
(0.00)\end{array}$ \\
\hline Water & $\begin{array}{c}-0.1386^{* * * *} \\
(0.00)\end{array}$ & $\begin{array}{c}-0.0293^{*} \\
(0.06) \\
\end{array}$ & $\begin{array}{c}-0.0077^{*} * * \\
(0.00)\end{array}$ & $\begin{array}{c}-0.1094^{* * * *} \\
(0.00)\end{array}$ & $\begin{array}{c}-0.0292^{* *} \\
(0.02) \\
\end{array}$ & $\begin{array}{c}-0.0143^{* * *} \\
(0.00)\end{array}$ \\
\hline Sanitation & $\begin{array}{c}0.0143 \\
(0.7)\end{array}$ & $\begin{array}{c}-0.0026 \\
(0.8)\end{array}$ & $\begin{array}{c}0.0011 \\
(0.6)\end{array}$ & $\begin{array}{c}-0.0071 \\
(0.8)\end{array}$ & $\begin{array}{c}-0.0156 \\
(0.51)\end{array}$ & $\begin{array}{c}-0.0031 \\
(0.4)\end{array}$ \\
\hline Goveff & & & & $\begin{array}{c}-1.3145 \\
(0.2) \\
\end{array}$ & $\begin{array}{c}1.1832^{*} \\
(0.08)\end{array}$ & $\begin{array}{c}0.8219^{* * *} \\
(0.00)\end{array}$ \\
\hline Polist & & & & $\begin{array}{c}0.5806 \\
(0.3)\end{array}$ & $\begin{array}{c}-0.2322 \\
(0.6)\end{array}$ & $\begin{array}{c}-0.0995 \\
(0.18)\end{array}$ \\
\hline Lag dependant & $\begin{array}{c}0.9386^{* * * *} \\
(0.00)\end{array}$ & $\begin{array}{c}1.0216^{* * * *} \\
(0.00)\end{array}$ & $\begin{array}{c}0.9974 * * * \\
(0.00)\end{array}$ & $\begin{array}{c}0.9412^{* * *} \\
(0.00)\end{array}$ & $\begin{array}{c}1.0123^{* * * *} \\
(0.00)\end{array}$ & $\begin{array}{c}1.0123^{* * * *} \\
(0.00)\end{array}$ \\
\hline Cons & $\begin{array}{c}22.5369^{* * * *} \\
(0.00)\end{array}$ & $\begin{array}{c}5.1348^{* * * *} \\
(0.00)\end{array}$ & $\begin{array}{c}2.3424 * * * \\
(0.00)\end{array}$ & $\begin{array}{c}19.9513^{* * * *} \\
(0.00)\end{array}$ & $\begin{array}{c}8.8303^{* * *} * \\
(0.00)\end{array}$ & $\begin{array}{c}3.5026^{* * * *} \\
(0.00)\end{array}$ \\
\hline $\operatorname{AR}(1)$ & 0.02 & 0.02 & 0.00 & 0.02 & 0.02 & 0.00 \\
\hline $\operatorname{AR}(2)$ & 0.92 & 0.13 & 0.45 & 0.88 & 0.13 & 0.40 \\
\hline Sargan & 0.98 & 0.21 & 0.92 & 0.98 & 0.19 & 0.93 \\
\hline Hansen & 0.99 & 0.75 & 0.34 & 0.727 & 0.67 & 0.36 \\
\hline Instruments & 17 & 22 & 20 & 23 & 22 & 23 \\
\hline N. Obs. & 414 & 414 & 414 & 414 & 414 & 414 \\
\hline
\end{tabular}
probabilities.

In a nutshell, industrialization is at the origin of deskilling in SSA. Considering that industrialization can promote or improve per capita income (Kerr, 1962) and increased urbanization (Le Brun et al., 2011) what role can these factors play in the transmission of the effects of the manufacturing sector on education?

\subsection{Effect of Industrialization on Education: The Role of Income per Capita and Urbanization?}

Table 5 analyzes the indirect effect of manufacturing sector on education using per capita income and urbanization as potential transmission channels. Hence the introduction of the interaction variables Indust*gdpc and Indust*urban in the econometric model (1). These results are recorded in columns 7-9 for the income channel and those recorded in columns 10-12 relate to the urbanization channel. 
Table 5. The role of per capita income and urbanization in the relationship between industrialization and education.

\begin{tabular}{|c|c|c|c|c|c|c|c|c|c|c|c|c|}
\hline \multirow[t]{2}{*}{ Variables } & 1 & 2 & 3 & 4 & 5 & 6 & 7 & 8 & 9 & 10 & 11 & 12 \\
\hline & Education 1 & Education2 & Education3 & Education 1 & Education2 & Education3 & Education 1 & Education2 & Education3 & Education1 & Education2 & Education3 \\
\hline Indust & $\begin{array}{c}-0.1701^{*} * \\
(0.02)\end{array}$ & $\begin{array}{c}-0.0773^{*} * \\
(0.04)\end{array}$ & $\begin{array}{c}-0.0268^{* *} \\
(0.02)\end{array}$ & $\begin{array}{c}-0.1439^{*} \\
(0.06)\end{array}$ & $\begin{array}{c}-0.0762 * * \\
(0.02)\end{array}$ & $\begin{array}{c}-0.0267^{*} * * \\
(0.00)\end{array}$ & $\begin{array}{c}-0.1975^{*} \\
(0.08)\end{array}$ & $\begin{array}{c}-0.1806^{* * *} \\
(0.00)\end{array}$ & $\begin{array}{c}-0.0634^{* * * *} \\
(0.00)\end{array}$ & $\begin{array}{c}-0.3925^{*} \\
(0.05)\end{array}$ & $\begin{array}{c}-0.3712^{* * * *} \\
(0.00)\end{array}$ & $\begin{array}{c}-0.0992^{*} * * \\
(0.00)\end{array}$ \\
\hline Agricul & $\begin{array}{c}-0.104^{* * * *} \\
(0.00)\end{array}$ & $\begin{array}{c}0.0047 \\
(0.8)\end{array}$ & $\begin{array}{c}-0.0078^{* * * *} \\
(0.00)\end{array}$ & $\begin{array}{c}-0.1510^{* * * *} \\
(0.00)\end{array}$ & $\begin{array}{c}-0.0351^{* *} * \\
(0.02)\end{array}$ & $\begin{array}{c}-0.0020 \\
(0.5)\end{array}$ & $\begin{array}{c}-0.1436^{* * * *} \\
(0.00)\end{array}$ & $\begin{array}{c}-0.0454^{* * * *} \\
(0.00)\end{array}$ & $\begin{array}{c}-0.0094^{* * * *} \\
(0.00)\end{array}$ & $\begin{array}{c}-0.1381 * * * \\
(0.00)\end{array}$ & $\begin{array}{c}-0.0742^{* * *} * \\
(0.00)\end{array}$ & $\begin{array}{c}-0.0074^{*} \\
(0.08)\end{array}$ \\
\hline Pop & $\begin{array}{c}-0.0088 \\
(0.9)\end{array}$ & $\begin{array}{c}-1.334^{*} * * * \\
(0.00)\end{array}$ & $\begin{array}{c}-0.3487^{* * * *} \\
(0.00)\end{array}$ & $\begin{array}{c}-0.3747 \\
(0.4)\end{array}$ & $\begin{array}{c}-0.7792^{* *} \\
(0.04)\end{array}$ & $\begin{array}{c}-0.4542^{* * *} * \\
(0.00)\end{array}$ & $\begin{array}{c}-0.6653 \\
(0.2)\end{array}$ & $\begin{array}{c}-0.9583^{* * * *} \\
(0.00)\end{array}$ & $\begin{array}{c}-0.4098^{*} * * * \\
(0.00)\end{array}$ & $\begin{array}{c}-1.3150^{*} \\
(0.05)\end{array}$ & $\begin{array}{c}-0.7636^{*} \\
(0.07)\end{array}$ & $\begin{array}{c}-0.5630^{* * * *} \\
(0.00)\end{array}$ \\
\hline Water & $\begin{array}{c}-0.052^{* * * *} \\
(0.00)\end{array}$ & $\begin{array}{c}-0.043^{*} * * * * \\
(0.00)\end{array}$ & $\begin{array}{c}-0.0076^{* * *} \\
(0.00)\end{array}$ & $\begin{array}{c}-0.060^{* * * *} \\
(0.00)\end{array}$ & $\begin{array}{c}-0.0327^{* *} * \\
(0.02)\end{array}$ & $\begin{array}{c}-0.1278^{* * *} * \\
(0.00)\end{array}$ & $\begin{array}{c}-0.0652^{* * * *} \\
(0.00)\end{array}$ & $\begin{array}{c}-0.0446^{* * *} * \\
(0.00)\end{array}$ & $\begin{array}{c}-0.0127^{* * * *} \\
(0.00)\end{array}$ & $\begin{array}{c}-0.1517^{* * *} \\
(0.00)\end{array}$ & $\begin{array}{c}-0.0064 \\
(0.6)\end{array}$ & $\begin{array}{c}-0.0135 * * * * \\
(0.00)\end{array}$ \\
\hline Sanitation & $\begin{array}{c}-0.0023 \\
(0.9)\end{array}$ & $\begin{array}{c}0.0282 \\
(0.3)\end{array}$ & $\begin{array}{c}0.0042 \\
(0.1)\end{array}$ & $\begin{array}{c}-0.0457 \\
(0.1)\end{array}$ & $\begin{array}{c}-0.0123 \\
(0.5)\end{array}$ & $\begin{array}{c}0.0030 \\
(0.3)\end{array}$ & $\begin{array}{c}-0.0772^{*} * \\
(0.02)\end{array}$ & $\begin{array}{c}-0.0139 \\
(0.4)\end{array}$ & $\begin{array}{c}-0.0021 \\
(0.5)\end{array}$ & $\begin{array}{c}-0.0190 \\
(0.4)\end{array}$ & $\begin{array}{c}-0.0384^{*} \\
(0.07)\end{array}$ & $\begin{array}{c}-0.0043 \\
(0.3)\end{array}$ \\
\hline Gdpc & $\begin{array}{c}-0.0003 \\
(0.3)\end{array}$ & $\begin{array}{c}-0.9 \mathrm{E}^{-3} * * * \\
(0.00)\end{array}$ & $\begin{array}{c}-0.6 \mathrm{E}^{-4} * * * \\
(0.00)\end{array}$ & & & & $\begin{array}{c}-0.0011^{*} \\
(0.06)\end{array}$ & $\begin{array}{c}-0.0012^{* * *} * \\
(0.00)\end{array}$ & $\begin{array}{c}-0.0002^{* * *} * \\
(0.00)\end{array}$ & & & \\
\hline Urban & & & & $\begin{array}{c}-0.0305 \\
(0.1)\end{array}$ & $\begin{array}{c}-0.0106 \\
(0.4)\end{array}$ & $\begin{array}{c}0.0169 * * \\
(0.03)\end{array}$ & & & & $\begin{array}{c}-0.1578^{*} \\
(0.05)\end{array}$ & $\begin{array}{c}-0.1594 * * * \\
(0.00)\end{array}$ & $\begin{array}{c}-0.0174 \\
(0.1)\end{array}$ \\
\hline Indus*gdpc & & & & & & & $\begin{array}{c}0.0001 * * \\
(0.04)\end{array}$ & $\begin{array}{c}0.0001^{* * * *} \\
(0.00)\end{array}$ & $\begin{array}{c}-0.3 \mathrm{E}^{-4 * * *} \\
(0.00)\end{array}$ & & & \\
\hline Indust*urban & & & & & & & & & & $\begin{array}{c}0.0150^{*} \\
(0.06)\end{array}$ & $\begin{array}{c}0.0151^{*} * * \\
(0.01)\end{array}$ & $\begin{array}{c}0.0041^{*} * * * \\
(0.00)\end{array}$ \\
\hline $\begin{array}{l}\text { Lag } \\
\text { Dependant }\end{array}$ & $\begin{array}{c}0.9172^{* * *} \\
(0.00)\end{array}$ & $\begin{array}{c}1.0622^{* * *} * \\
(0.00)\end{array}$ & $\begin{array}{c}1.0059^{*} * * \\
(0.00)\end{array}$ & $\begin{array}{c}0.9109^{* * * *} \\
(0.00)\end{array}$ & $\begin{array}{c}1.0304 * * * \\
(0.00)\end{array}$ & $\begin{array}{c}0.9901^{* * *} * \\
(0.00)\end{array}$ & $\begin{array}{c}0.9345^{* * *} * \\
(0.00)\end{array}$ & $\begin{array}{c}1.0408^{* * * *} \\
(0.00)\end{array}$ & $\begin{array}{c}1.0058^{* * * *} \\
(0.00)\end{array}$ & $\begin{array}{c}0.9470^{* * * *} \\
(0.00)\end{array}$ & $\begin{array}{c}1.0100^{*} * * * \\
(0.00)\end{array}$ & $\begin{array}{c}0.9884^{* * *} \\
(0.00)\end{array}$ \\
\hline Cons. & $\begin{array}{c}16.985^{* * * * *} \\
(0.00)\end{array}$ & $\begin{array}{c}6.1220^{* * * *} \\
(0.00)\end{array}$ & $\begin{array}{c}2.0395^{*} * * * \\
(0.00)\end{array}$ & $\begin{array}{c}21.023^{*} * * * * \\
(0.00)\end{array}$ & $\begin{array}{c}6.1907^{*} * * * \\
(0.00)\end{array}$ & $\begin{array}{c}2.2756^{* * * *} \\
(0.00)\end{array}$ & $\begin{array}{c}20.480^{* * * *} \\
(0.00)\end{array}$ & $\begin{array}{c}8.3697^{*} * * * \\
(0.00)\end{array}$ & $\begin{array}{c}2.9249^{* * * *} \\
(0.00)\end{array}$ & $\begin{array}{c}26.091^{* * * *} \\
(0.00)\end{array}$ & $\begin{array}{c}9.8279^{*} * * * * \\
(0.00)\end{array}$ & $\begin{array}{c}3.5166^{*} * * * \\
(0.00)\end{array}$ \\
\hline Net effect & - & - & - & - & - & - & -0.0821 & -0.0652 & -0.0287 & -0.1573 & -0.1344 & -0.0349 \\
\hline Thereshold & - & - & - & - & - & - & 1975 & 1806 & 2113,33 & 26.16 & 24.58 & 24.19 \\
\hline $\operatorname{AR}(1)$ & 0.02 & 0.03 & 0.00 & 0.02 & 0.02 & 0.00 & 0.02 & 0.02 & 0.00 & 0.02 & 0.03 & 0.00 \\
\hline $\operatorname{AR}(2)$ & 0.93 & 0.12 & 0.44 & 0.92 & 0.13 & 0.46 & 0.98 & 0.13 & 0.46 & 0.98 & 0.14 & 0.54 \\
\hline Sargan & 0.62 & 0.57 & 0.89 & 0.64 & 0.21 & 0.9 & 0.6 & 0.48 & 0.90 & 0.93 & 0.18 & 0.87 \\
\hline Hansen & 0.19 & 0.78 & 0.41 & 0.16 & 0.77 & 0.40 & 0.35 & 0.7 & 0.56 & 0.67 & 0.56 & 0.52 \\
\hline Instruments & 23 & 22 & 20 & 23 & 23 & 20 & 22 & 23 & 20 & 21 & 23 & 20 \\
\hline N. Obs. & $4: 14$ & 414 & 4114 & 414 & 4114 & 414 & 414 & 414 & 414 & 414 & 414 & 414 \\
\hline
\end{tabular}

Note : The significance thresholds at $1 \%, 5 \%$ and $10 \%$ are represented by $* * * * * *$ and $*$ respectively. Values below the coefficients and in parentheses represent probabilities. 
In addition to the fact that the results obtained from Table 5 validate the inverse relationship between the manufacturing sector and education (columns 1-12), the coefficients of the interaction variables Manuf*gdpc (columns 7-9) and Manuf*urban (columns 10-12) favorably impacts the three levels of education. Moreover, these results reveal that there is a per capita income threshold and an urbanization threshold beyond which the manufacturing sector contributes positively to education in SSA. Considering that the sign of the indirect effect (the interaction variable) is different from the sign of the direct effect (thus reflecting the absence of synergistic effect), net effects can be generated according to recent works (Asongu \& Nchofoung, 2021; Asongu \& Nwachukwu, 2017). In the calculation process, the net effects of the effect of the interaction of per capita income with industrialization are -0.082 1 for primary education (column 7). This value is obtained as $\left(-0.1975+\left(1153.37^{*} 0.001\right)\right)$. In this calculation, 0.0001 is the interactive effect coefficient, -0.1975 is the direct effect coefficient, and 1153.37 is the average per capita income as shown in the descriptive statistics table. Applying the above calculation in all our transmission mechanisms, it is evident that despite the positive interactive effect of per capita income and urbanization variables in transmitting the effect of industrialization on education, the effect direct negative exceeds this positive interactive effect producing net negative effects of industrialization on education in our sample.

The policy thresholds of per capita income and urbanization variables that cancel out the negative effect of manufacturing on education in our sample are $(1975 ; 26.16),(1806 ; 24.58)$ and $(2113.33 ; 24,19)$ respectively for first, second and third level of education. The threshold of a variable is obtained by setting the derivative of the manufacturing sector with respect to this variable equal to zero. Simply put, the threshold is the ratio of the unconditional to that of the conditional effect. All of these threshold values (income per capita; urbanization) have policy implications here, as they fall within the range of values reported in the descriptive statistics $(149.36<$ Income per capita threshold $<8080.86$ and $4,27<$ Threshold of urbanization $<64.20$ ). Thus, for industrialization to have a positive impact on education, per capita income would have to be higher than 1975.1806 and 2113.33 US dollars respectively for primary, secondary and tertiary education. Similarly, for industrialization to have a positive impact on education, urbanization would have to be greater than 26.26; 24.58 and 24.19 respectively for the first, second and third level of education.

\section{CONCLUSION}

Several studies have focused on the determinants of education. However, no study has focused on the relationship between manufacturing and education, especially in SSA countries. This work seeks to fill this limitation of the literature by analyzing this relationship in 23 countries during the period 2000-2018. To carry out our study, we used Driscoll and Kraay estimation techniques and System GMMs. In summary, three main findings emerge from this study. The first result reveals that there is an inverse relationship between the manufacturing sector and the three levels of education. The second result confirms that per capita income as well as urbanization are transmission channels through which SSA can improve the efficiency of the industrialization process towards education. Finally, the positive effect of industrialization on education is linked to the achievement of a certain per capita income threshold and a certain urbanization threshold in Sub-Saharan Africa. Thus, Sub-Saharan African countries need to put in place mechanisms to further increase their per capita income on the one hand and develop sustainable urbanization on the other in order to reap the benefits of industrialization at all three levels of education. Moreover, the acceleration of the industrialization process is a necessity to achieve this.

Funding: This study received no specific financial support.

Competing Interests: The authors declare that they have no competing interests.

Authors' Contributions: All authors contributed equally to the conception and design of the study.

Views and opinions expressed in this study are the authors' views and opinions; the Asian Journal of Empirical Research shall not be responsible or answerable for any loss, damage, or liability, etc. caused in relation to/arising out of the use of the content.

\section{REFERENCES}

AfDB. (2017). Industrialize Africa, strategies, policies, institutions and financing. Retrieved from: http://bit.ly/2AfU14P.

Arellano, M., \& Bond, S. (1991). Some tests of specification for panel data: Monte Carlo evidence and an application to employment equations. The Review of Economic Studies, 58(2), 277-297.Available at: https://doi.org/10.2307/2297968.

Arellano, M., \& Bover, O. (1995). Another look at the instrumental variable estimation of error-components models. Journal of Econometrics, 68(1), 29-51.Available at: https://doi.org/10.1016/0304-4076(94)01642-d.

Asongu, S., \& Nchofoung, T. (2021). The terrorism-finance nexus contingent on globalisation and governance dynamics in Africa. European Xtramile Centre of African Studies No. WP/21/016.

Asongu, S. A., \& Nwachukwu, J. C. (2017). Foreign aid and inclusive development: Updated evidence from Africa, 2005-2012. Social Science Quarterly, 98(1), 282-298.Available at: https://doi.org/10.1111/ssqu.12275.

Becker, G. S. (1962). Investment in human capital: A theoretical analysis. Journal of Political Economy, $70(5$, Part 2$)$, 9-49.

Bilsborrow, R. E. (1978). The relationship between population growth and the expansion of education systems in developing countries 1950-1970. The Pakistan Development Review, 17(2), 212-232.Available at: https://doi.org/10.30541/v17i2pp.212-232.

Blundell, R., \& Bond, S. (1998). Initial conditions and moment restrictions in dynamic panel data models. Journal of Econometrics, $87(1), 115-143$.

Cadot, O., De Melo, J., Plane, P., Wagner, L., \& Woldemichael, M. (2016). Industrialization and structural transformation: Can SubSaharan Africa grow without factories? Review of Development Economics, 24(2), 19-49. 
Corbin, A. (1975). For a sociological study of the growth of literacy in the XIX th century: The instruction of conscripts from Cher and Eure-et-Loir (1833-1883). Review of Economic and Social History, 53(1), 99-120.

De Pleijt, A., \& Weisdorf, J. (2016). Human capital formation from occupations: The "deskilling hypothesis" revisited. Cliometrica, $11(1), 1-30$.

De Pleijt, A. M. (2018). Human capital formation in the long run: Evidence from average years of schooling in England, 1300-1900. Cliometrica, 12(1), 99-126.

Duarte, M., \& Restuccia, D. (2010). The role of the structural transformation in aggregate productivity. The Quarterly Journal of Economics, 125(1), 129-173.

Engler, S., \& Kretzer, M. M. (2014). Agriculture and education: Agricultural education as an adaptation to food insecurity in Malawi. Universal Journal of Agricultural Research, 2(6), 224-231.

Federman, M., \& Levine, I. D. (2005). The effects of industrialization on education and youth labor in Indonesia. Contributions in Macroeconomics, 5(1), 1-34.

Goldin, C., \& Katz, L. F. (1999). Human capital and social capital: The rise of secondary schooling in America, 1910-1940. Journal of Interdisciplinary History, 29(4), 683-723.

Goldin, C., \& Katz, L. (1997). Why United States led in education: Lessons from secondary school expansion, 1910 to 1940. NBER Working Paper No. (6144).

Goujon, M., \& Kafando, C. (2011). Structural characteristics and industrialization in Africa: A preliminary exploration. CERDI, Studies and Documents, E 2011.33.

Hausmann, R., Pritchett, L., \& Rodrik, D. (2005). Growth accelerations. Journal of Economic Growth, 10(4), 303-329.Available at: https://doi.org/10.1007/s10887-005-4712-0

Institute of Statistics for UNESCO. (2019). SDG 4 data digest how to produce and use the global and thematic education indicators.

Kerr, I. D. C. (1962). Harbinson and Meyers, C.A: Industrialisation industrial man (pp. 37). London: Heinemann Book Ltd.

Laqueur, T. W. (1974). Literacy and social mobility in the industrial revolution in England. Past \& Present, 64(1), 96-107.Available at: https://doi.org/10.1093/past/64.1.96.

Le Brun, A., Helper, S., \& Levine, D. I. (2011). The effect of industrialization on children's education-the experience of Mexico. Review of Economics and Institutions, 2(2), 1-34.

Leblond, M. (1970). Schooling in the Nord department in the 19th century. Northern Review, 52(206), 387-398.

Lucas, R. E. (1990). Why doesn't capital flow from rich to poor countries? The American Economic Review, 80(2), 92-96.

Marx, K., \& Engels, F. (1848). The communist manifesto. Arlington Heights, Ill: Harlan Davidson.

Mincer, J. (1958). Investment in human capital and personal income distribution. Journal of Political Economy, 66(4), 281302.Available at: https://doi.org/10.1086/258055.

Nardinelli, C. (1980). Child labor and the factory acts. The Journal of Economic History, 4O(4), 739-755.Available at: https://doi.org/10.1017/s0022050700100166.

Nardinelli, C. (1990). Child labor and the industrial revolution. Bloomington: Indiana University Press.

Nicholas, S. J., \& Nicholas, J. M. (1992). Male literacy," deskilling," and the industrial revolution. The Journal of Interdisciplinary History, 23(1), 1-18.Available at: https://doi.org/10.2307/205479.

Nickell, S. (1981). Biases in dynamic models with fixed effects. Econometrica, 49(6), 1417-1426.Available at: https://doi.org/10.2307/1911408.

Njangang, H., \& Nounamo, Y. (2020). Is information and communication technology a driver of industrialization process in African countries? Economics Bulletin, 4O(4), 2654-2662.

Nkoa, B. E. O. (2016). Foreign direct investment and the industrialization of Africa: A new perspective. Innovations, 51(3), 173196.Available at: https://doi.org/10.3917/inno.051.0173.

Pesaran, M. H. (2004). General diagnostic tests for cross section dependence in panels. IZA Discussion Paper No. 1240 Institute for the Study of Labor (IZA).

Rodrik, D. (2008). One economics, many recipes: Globalization, institutions, and economic growth Princeton, $N J$ (pp. 280). Princeton University Press.

Rodrik, D. (2009). Growth after the crisis. Cambridge, MA: Harvard Kennedy School.

Sanderson, M. (1972). Literacy and social mobility in the industrial revolution in England. Past and Present, 56(1), 75-103.Available at: https://doi.org/10.1093/past/56.1.75.

Santiago, O.-C. J., Resende, F. M., \& Dinar, A. (2016). Impact of access to water and sanitation services on educational attainment. Water Resources and Economics, 14, 31-43.Available at: https://doi.org/10.1016/j.wre.2015.1 1.002.

Schofield, R. (1973). Dimensions of illiteracy, 1750-1850. Explorations in Economic History, 10(4), 437-454.Available at https://doi.org/10.1016/0014-4983(73)90026-0.

Sharma, V. K., Vashist, R. L., \& Sharma, N. (2008). An empirical analysis of the impact of industrialization on infrastructure development in Himachal Pradesh. Asia Pacific Business Revier, 4(2), 90-101.Available at https://doi.org/10.1177/097324700800400211.

Smith, A. (1776). An inquiry into the nature \& causes of the wealth of nations. Oxford: The Clarendon Press.

Tendler, J. (2002). The fear of education. Massachusetts Institute of Technology. Retrieved from https://media.entopanlab.it/storage/achii/media/judith-tendler/2000-2011/fear_of_education.pdf.

UN. (2015). Millenium objectives for development 2015 report. Retrieved from: https://www.un.org/fr/millenniumgoals/reports/2015/pdf.

UNCTAD, \& UNIDO. (2011). Fostering industrial development in Africa in the new global environment. Economic Development in Africa Report 2011.

UNIDO. (2002). UNIDO industrial development report 2002-2003: Africa handicapped by its technological backwardness. New York: UNIDO.

World Bank. (2016). World development indicators. Washington D.C: World Bank. 


\section{APPENDICES}

Table A1. List of countries.

\begin{tabular}{l|l|l|l}
\hline Angola & Guinea & Nigeria & Zambia \\
\hline Burkina Faso & Kenya & Senegal & Zimbabwe \\
\hline Cameroon & Madagascar & Sierra Leone & \\
\hline Chad & Malawi & Soudan & \\
\hline Congo & Mali & South Africa & \\
\hline Congo, Dem. Rep & Mozambique & Tanzania & \\
\hline Cote d'Ivoire & Niger & Uganda & \\
\hline
\end{tabular}

Table A2. Variable definitions

\begin{tabular}{|c|c|c|c|}
\hline Variables & Signs & Variables Definition (Measurement) & Sources \\
\hline Manufacturing & Manuf & Manufacturing, value added (\% of GDP). & World Bank (WDI) \\
\hline Agriculture & Agriculture & Added value of agriculture (\% of GDP). & World Bank (WDI) \\
\hline $\begin{array}{l}\text { Gross Domestic } \\
\text { Product per Capita }\end{array}$ & GDPC & $\begin{array}{l}\text { Gross Domestic Product (GDP) per capita growth (annual } \\
\%) \text {. }\end{array}$ & World Bank (WDI) \\
\hline Primary education & Primary & School enrollment, primary (\% gross). & World Bank (WDI) \\
\hline Secondary education & Secondary & School enrollment, secondary (\% gross). & World Bank (WDI) \\
\hline Water & Water & $\begin{array}{l}\text { People using at least basic drinking water services (\% of } \\
\text { population). }\end{array}$ & \\
\hline Tertiary education & Tertiary & School enrollment, Tertiary (\% gross). & World Bank (WDI) \\
\hline Sanitation & Sanitation & $\begin{array}{l}\text { People using at least basic sanitation services }(\% \text { of } \\
\text { population). }\end{array}$ & World Bank (WDI) \\
\hline Political stability & Plista & $\begin{array}{l}\text { Political stability and absence of violence/terrorism } \\
\text { measures perceptions of the likelihood of political } \\
\text { instability and/or politically motivated violence, including } \\
\text { terrorism. The estimate gives the country's score on the } \\
\text { aggregate indicator, in units of a standard normal } \\
\text { distribution, i.e. ranging from around }-2.5 \text { to } 2.5 \text {. }\end{array}$ & WGI, World Bank \\
\hline Urbanization & Urban & $\begin{array}{l}\text { Population in urban agglomerations of more than } 1 \text { million } \\
\text { (\% of total population). }\end{array}$ & World Bank (WDI) \\
\hline
\end{tabular}

